\title{
TRANSFORMATIONAL LOGIC AND SOCIAL TRANSFORMATION
}

\begin{abstract}
This paper presents the basics of Academic Brutian's conception of transformational logic and the application of its methodological means to the study of optimal ways for transforming former socialist system of Armenia into social state in the frame of capitalist free market economy.
\end{abstract}

Keywords: transformational logic, transformational analysis, social transformation.

The author of transformational logic - academician Georg Brutian - intended to develop rules for transforming implicit forms of thought into explicit ones. (Brutian 1984, 1995, 1998.) Later it has been realized that the field of transformational logic was much broader yet mainly bounded to processes of thinking and epistemology. (Djidjian 1992, 2004, 2006.) This kind epistemological extension of Brutian's conception is quite natural since his main concept of forms of thought rises from the task of generalizing scientific thinking and its laws. The specific side of transformational logic is that that it starts by revealing implicit forms of thought and knowledge which is the cardinal part of analytic thinking. Thus the epistemological extension of transformational logic brings us directly to the procedures of analysis.

Reading through pages of Georg Brutian's works on transformational logic one can clearly realize that all the revealed implicit forms of thought, just because of their implicit nature, keep some significant features of these forms in shade or even in obscurity. Just for overcoming this kind uncertainties of implicit forms transformational logic suggests building a system of rules for transforming them into explicitly described forms. In actuality, the implicit forms of thought are closely related to certain logical problems that get their resolution in explicit formulations and descriptions. Thus we realize that the main stream methodology of transformational logic factually deals with problems of refining particular conceptions of forms of thought. The above said reveals that the studies of forms of thought in transformational logic start by problem analysis. Not to lose the connection with original transformational logic we have introduced the term transformational analysis to denote the procedures of problem analysis under the guidance of the general strategy of transformational logic.

Saying alpha, namely, "transformational analysis", we have to say beta also, namely, "transformational synthesis". We have shown earlier (Djidjian 2004) that the process of problem solution comprises two main phases - problem analysis and the synthesis of the idea of solution (or using the popular term, idea generation). Actually, in Academician Brutian's logical system an explicit form is uncovered by solution of the task of reaching the perfect formulation of the corresponding implicit form. Just for this goal G. Brutian has suggested a number of transformational rules. The system of transformational rules should generate ideas for transforming an implicit form of thought into corresponding explicit form. 
In recent years Academician Brutian deliberated on the ways of connecting the strategy of his transformational logic to the problems of transforming modern society of which goal I was told by his close colleagues. This paper is the first step in applying transformational analysis to problems of modern dynamic social life.

The first thing required by G.Brutian's strategy of transformational logic is to explicate the main forms and factors implicitly contained and at the same time dominating the processes of social transformation. In fact, the $20^{\text {th }}$ century was an epoch of great social experiments. So to reveal the optimal ways of transforming modern society one has to use transformational analysis for explicating the concrete factors of radical social changes of the past century.

It was a thunder in the blue sky when in October 1917 a tiny Bolshevik group seized power in wartorn Russia. Eventually, Lenin's genius transformed Russia into a socialist society of which has dreamed many noble souls beginning with Thomas More and Tommaso Campanella. Not less suddenly happened the democratic counter-revolution in 1991 that broke to pieces the mighty Soviet Empire along with socialist society.

Did the liberal-democratic new Russian elite intend transforming the country into free capitalist society of the people, by the people, and for the people? Actually, Russian people was robbed by Boris Yeltsin "family" and friends of all its immense wealth by a filthy mechanism of vouchers and as the result Russia was pushed down into the precipice of irredeemable poverty. The picture was not much different in all other post-Soviet republics.

The first years of transforming the soviet Communist party dictatorship into free market capitalist freedom were so disastrous and ruthless that one has to try forgetting these unforgivable inhuman acts of liberal elite rabble and regaining one's piece of mind by recalling the old saying: each people deserves the government it has. Yet there remains the important problem: is it possible to suggest a universal general strategy for transforming each of post-soviet republics into a descent capitalist society more or less like that of present day democratic Germany?

The answer to this question could be only negative. Because former soviet Baltic republics are already members of European Union, Turkmenistan and Uzbekistan would abstain becoming free market democracy as long as they have enough gas and oil, while each of remaining post-soviet republics has its own unique problems extremely hard to resolve.

Thus we land into Armenia with its economic and political specific hardships, while the ways of overcoming them still remain unknown. Returning again to the academician Brutian's rules of transformational logic and its strategic line of transforming implicit factors into explicitly conceivable causes let us thoroughly examine the causes that prevent radical improvement of social-economic situation in present-day Armenia.

What are the most influential negative factors in social-economical life of modern Armenia that hamper radical social-economic progress of this country? Unfortunately many of them are negative. The most apparent factor is the tragic conflict over Nagorno-Karabakh. The 25 years of the smoldering conflict do not show any sign of progress for its solution despite the continuous efforts of international committees that include USA, European Union, and Russia. The second factor is represented by the Armenian industry and agriculture that have been broken down by pseudo-democratic politicians and criminal vouchers. The third negative factor is the Armenian old tradition to foster radical and rapid social- 
cultural changes. We have been first establishing in 301 a Christian state and by the way destroying ancient non-Christian temples in Armenia. History repeated itself in the first two decades of communist power in Soviet Armenia when Bolshevik leaders closed down almost all churches in countryside and turned them into stockrooms for collective farm garbage. The fourth negative factor is more apparent. I mean the mass emigration of Armenians from Armenia.

Apart of the above mentioned negative factors there is a quite certain though not so much apparent danger of social-political instability in Armenia. This danger is Ukraine example, or more correctly, the ease by which anti-government politicians came to power in Kiev supported by European and American official and non-official advisers and finance.

After explicitly formulating the concrete problems that has to face the contemporary Armenian society on its road to social-economic progress, following Academician Brutian's strategy we have to apply his instrument of transformational analysis to each of the above outlined dominating negative factors. So we start investigating the ways by which the conflict over Nagorno-Karabakh could reach its solution. The most influential factor here is the deepest conviction of each side of conflict in the undoubted justice of its position. No Azeri would agree to any solution except of returning Nagorno-Karabakh to Azerbaijan, and no Armenian would agree to any solution except of full independence of Nagorno-Karabakh people.

Is this kind conflict between two nations so much unique for our time? Not, for sure. There are similar conflicts from the times of IRA fighting for Northern Ireland and ETA fighting for Basque independence, both of them far from being finally resolved. There are also sibling conflicts of Abkhaz people fighting for its independent state and the people of the South Ossetia fighting for its national statue.

Eve Conant sums up her vision of the conflicting world: "When it comes to territorial disputes across the globe, the list is long and ever-changing. There are now more than 150 disputes under way that involve territory, mostly in Africa, Asia, and the Pacific region, but also in Europe and the Americas. Some disputes are on the distant horizon (Antarctica), some are long-simmering (Jammu and Kashmir), and others-like Crimea-are at their boiling point" (Conant 2014). E. Conant list underlies China's troubles over Tibet, India and Pakistan dispute over Kashmir, Israeli occupation of Syrian Golan Heights and Palestinian territories, Morocco old dispute over Western Sahara. Other lists of disputed territories mention also Falkland Islands, Gibraltar, Cyprus, Kosovo and many others.

What is the solution for this constantly expending mode of contemporary international and interethnic conflicts? Regarding this fundamental problem, the United Nations Charter declares: "All Members shall refrain in their international relations from the threat or use of force against the territorial integrity or political independence of any state, or in any other manner inconsistent with the Purposes of the United Nations. "But Kosovo case proves that no territorial and ethnic conflict could be resolved without applying international force and economic pressure.

Thus we come to a concrete solution: the United Nations should found a High Court for Territorial Ethnic Disputes, and all states and nations over the world should declare that they would accept any decision of the High Court even if it were against them. When the tradition of accepting the High Court decisions would spread by time all over the world, the tragic and bloody territorial conflicts between nations will radically decrease. Possibly this is the only way for resolving the territorial conflicts like that of Nagorno-Karabakh. 
Now let us consider the second factor - the state of affairs in Armenian industry and agriculture. The industry in Soviet time Armenia had two main directions: chemical industry and mining industry. To make the remnants of soviet time factories compatible with modern technologies needs huge investments, but few rich companies show interest in developing industries in this country. Perspectives are better in agriculture, especially in viniculture and animal breeding, though one needs new technologies here too. And to all the above described factors one should add the problem of the market for selling Armenian goods.

If one conceives adequately the huge importance of the market he would soon or later agree that only Russia could afford appropriate market for Armenian present-day produce and provide significant support for social-economic development of its historical ally. Not less important of theoretical considerations is the voice of practice: Armenian people have made his choice by mass emigration to Russian Federation. The present day economic and political situation in Armenia and around it requires from the Armenian state and government to build more close political ties and more intensive economic cooperation with Russia.

The third negative factor of Armenian old tradition to foster radical and rapid social-cultural changes could be significantly neutralized by well-organized propaganda. Of course it is hard to withstand the sweet dream of becoming a member of European Union and live there in economically stable and prospering society. But we have to realize that at present neither Armenia, nor EU are ready for such radical economic and social-cultural transformation. Stable progress is made by small steps. We have to fight for our European future first becoming economic success inside the Euro-Asian Union along with improving our traditions and values of social-political activities.

Armenian's social psychology is dominated by the highest value of his life - his children and family. All his life he works hard to make the life of his children happy. His children also work as hard as they can for the happiness of their children. And so on, generation after generation no Armenian gets spare time to make happy himself. Yet he compensates his life-long toil surrounding himself by beloved sweet grandchildren.

Yes, Armenian family is as stable as it could be in the dynamically changing global world. Yet family stability is important but not sufficient for the stability of the society as whole. Social life requires cooperation, regulation, loyalty to law, self-restraint, etc. And following all these requirements is not an easy thing for family-loving Armenian which makes socializing and acquiring law-abiding habit so significant to young Armenians and to many grownups. Becoming "good citizens" - that is what new Armenians have to learn to transform Armenia into social state.

The fourth negative factor of mass emigration from democratic and independent Armenia could be radically solved by intensive patriotic education of young generation. Meantime one can regulate the situation by introducing quotas of emigration - an analog of quotas of immigration effectively working in developed countries like United States and European Union.

With regard to new technologies of colored revolutions, I have the feeling that great powers can succeed in another democratic revolution any time they find the change of power necessary. With the exception of Armenia since as far as I understand Vladimir Putin would not allow it. 
Brutian, G.A. (1984). Transformational logic: Essential nature and basic concepts. Soviet Studies in Philiosophy, 1984, vol. 22, N 3, p. 3-22.

Brutian, G.A. (1995). Transformational logic. Yerevan, NAS RA "Science".

Brutian, G. (1998). Logic, Language, and Argumentation in Projection of Philosophical Knowledge. Lisbon: Armenian Library of Galouste Culbenkian Foundation, pp. 54-66.

Brutian, G.A., ed. (2008). Transformational logic. Books 1 and 2. Yerevan, International Academy for Philosophy publ.

Conant, E. (2014). Six of the World's Most Worrisome Disputed Territories.

http://news.nationalgeographic.com/news/2014/03/140328-disputed-territories-geography/

Djidjian, R. (1992). Transformational analysis and inner argumentation. // J. Pietarinen (ed.). Problems of philosophical argumentation. Vol. 5, Turku, 1992, pp. 80-93.

Djidjian, R. (2004). Getting Ready for Great Discoveries. Yerevan, Yerevan State University publ.

Djidjian, R. (2006). Transformational logic and the coming age of thinking machines. // News and Views, March, 2006, N 10, pp. 16-27.

Sumner, B.T. (2015). "Territorial Disputes at the International Court of Justice". Duke Law Journal. Retrieved September 6, 2015.

"List of Cases referred to the Court since 1946 by date of introduction". International Court of Justice. Retrieved September 6, 2015.

List of top 10 Territorial disputes:

http://listverse.com/2011/09/02/top-10-controversial-territorial-disputes 